\title{
The causes of flow regime shifts in the semi-arid Hailiutu River, Northwest China
}

\author{
Z. Yang ${ }^{1,2}$, Y. Zhou ${ }^{2}$, J. Wenninger ${ }^{2,3}$, and S. Uhlenbrook ${ }^{2,3}$ \\ ${ }^{1}$ School of Water Resources and Environment, China University of Geosciences (Beijing), 10029, Beijing, China \\ ${ }^{2}$ UNESCO-IHE Institute for Water Education, P.O. Box 3015, 2601 DA Delft, The Netherlands \\ ${ }^{3}$ Department of Water Resources, Delft University of Technology, P.O. Box 5048, 2600 GA Delft, The Netherlands
}

Correspondence to: Z. Yang (z.yang@unesco-ihe.org)

Received: 23 May 2011 - Published in Hydrol. Earth Syst. Sci. Discuss.: 23 June 2011

Revised: 25 December 2011 - Accepted: 2 January 2012 - Published: 10 January 2012

\begin{abstract}
Identifying the causes (climate vs. human activities) for hydrological variability is a major challenge in hydrology. This paper examines the flow regime shifts, changes in the climatic variables such as precipitation, evaporation, temperature, and crop area in the semi-arid Hailiutu catchment in the middle section of the Yellow River by performing several statistical analyses. The Pettitt test, cumulative sum charts (CUSUM), regime shift index (RSI) method, and harmonic analysis were carried out on annual, monthly, and daily discharges. Four major shifts in the flow regime have been detected in 1968, 1986, 1992 and 2001. Characteristics of the flow regime were analyzed in the five periods: 1957-1967, 1968-1985, 1986-1991, 1992-2000, and 2001-2007. From 1957 to 1967, the flow regime reflects quasi natural conditions of the high variability and larger amplitude of 6 months periodic fluctuations. The river peak flow was reduced by the construction of two reservoirs in the period 1968-1985. In the period of 1986-1991, the river discharge further decreased due to the combined influence of river diversions and increase of groundwater extractions for irrigation. In the fourth period of 1992-2000, the river discharge reached lowest flow and variation in corresponding to a large increase in crop area. The flow regime recovered, but not yet to natural status in the fifth period of 2001-2007. Climatic factors are found not likely responsible for the changes in the flow regime, but the changes in the flow regime are corresponding well to historical land use policy changes.
\end{abstract}

\section{Introduction}

The temporal pattern of river flow over a period of time is the river flow regime, which is a crucial factor sustaining the aquatic and riverine ecosystems. Regime shifts are defined in ecology as rapid reorganizations of ecosystems from one relatively stable state to another (Rodionov and Overland, 2005). Flow regime shifts represent relatively sudden changes in temporal characteristics of river discharges in different periods. It is widely accepted that climate change and human activities are the main driving forces for hydrological variability (e.g. Milliman et al., 2008; Zhao et al., 2009; $\mathrm{Xu}, 2011)$. However, distinguishing the causes for the flow regime shifts is still a major challenge in hydrology.

Studies show that flow regime shifts in river basins can be ascribed to the changes in climatic variables, land cover and land use, river regulations, and other human activities; for example, soil and water conservation measures. The climatic variables were considered as the major driving factors for long-term changes in river discharge (Arnell and Reynard, 1996; Neff et al., 2000; Middelkoop et al., 2001; Jha et al., 2004; Christensen et al., 2004; Wolfe et al., 2008; Timilsena et al., 2009; Masih et al., 2011). The impacts of future climate changes on stream discharge were also predicted (Gellens and Roulin, 1998; Chiew and McMahon, 2002; Eckhardt and Ulbrich, 2003; Drogue et al., 2004; Thodsen, 2007; Steele-Dunne et al., 2008). The changes in land cover (Matheussen et al., 2000; Cognard-Plancq et al., 2001; Costa et al., 2003; Bewket and Sterk, 2005; Poff et al., 2006; Guo et al., 2008) and land use (Fohrer et al., 2001; Tu, 2006; Zhang and Schilling, 2006; Rientjes et al., 2011; Masih et 


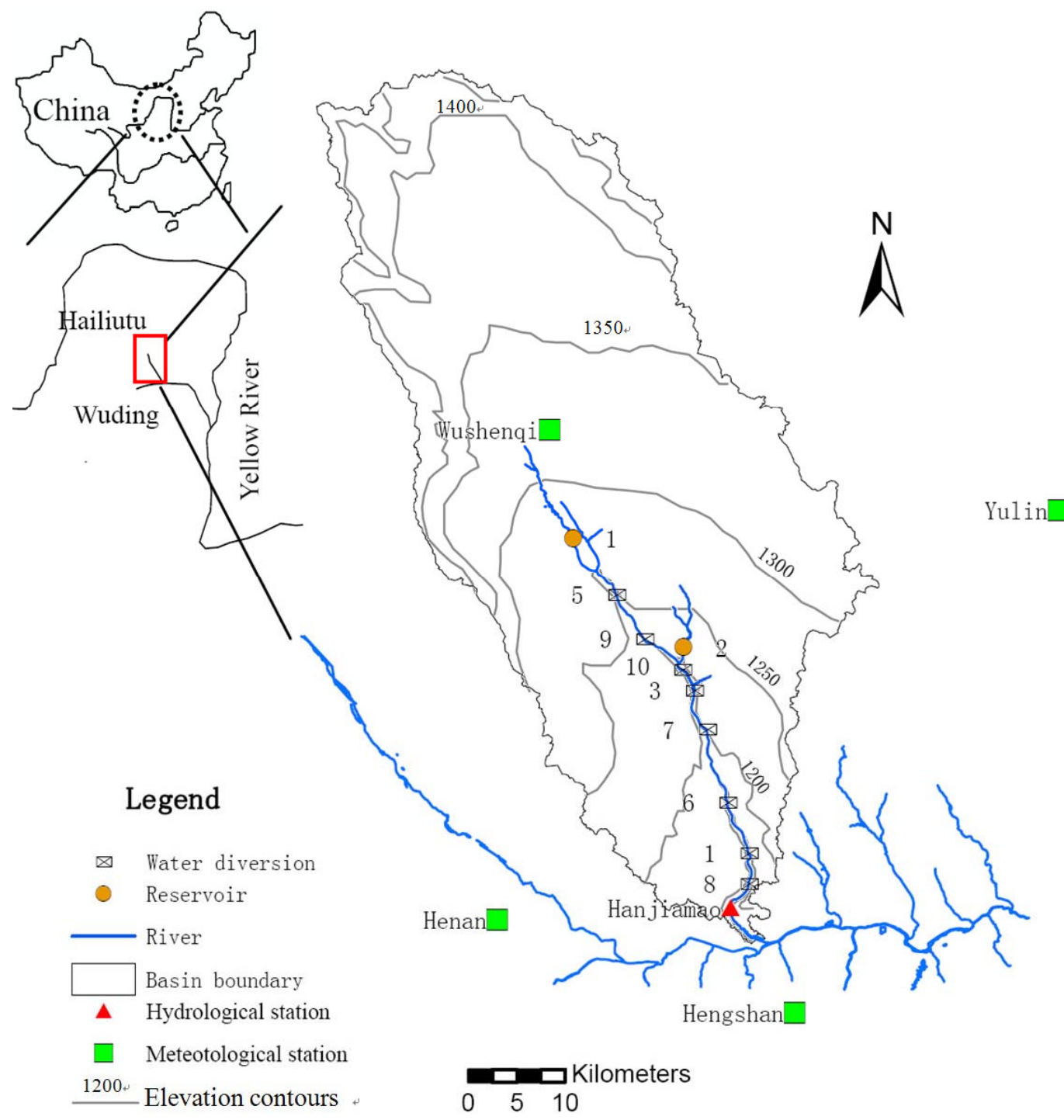

Fig. 1. Map of the Hailiutu catchment, the numbers nearby the stations are indices of hydraulic engineering works in the Table 1 .

al., 2011) would eventually alter the river discharge by influencing the runoff generation and infiltration processes. The construction of dams can significantly reduce the high flows and increase the low flows (Maheshwari et al., 1995; Magilliganan and Nislow, 2005). The hydrological response also depends on a combination of precipitation, evaporation, transpiration, basin permeability and basin steepness (Lavers et al., 2010) or runoff generation in headwater catchments, impoundments in small dams and increased extractions for irrigated crop production (Love et al., 2010). These studies mainly focused on the relationship between the mean annual stream flow and the corresponding factors by performing statistic tests on indicators of hydrological alterations or comparing modelled and measured discharges.

In China, the relations between the stream flow, precipitation and temperature were investigated in the Tarim River (Chen et al., 2006), Yellow River (Fu et al., 2007; Hu et al., 2011a), Wuding River (Yang et al., 2005) and Lijiang River (He et al., 2010). Zhao et al. (2009) studied the streamflow response to climate variability and human activities in the upper Yellow River Basin, and suggested that the climate effects accounted for about $50 \%$ of total streamflow changes while effects of human activities on streamflow accounted for about $40 \%$. But the type of human activities was not identified. Furthermore, the changes in river discharge induced by soil and water conservation measures were examined in the Loess Plateau (Li et al., 2007; Dou et al., 2009) and Wuding River (Xu, 2011). The effects of dam construction (Yang et al., 2008) and operation (Yan et al., 2010) on flow regimes in the lower Yellow River were assessed by analyzing the indicators of hydrological alterations (Richter et al., 1996), which suggested that dams affect the stream flow by increasing the low flows and decreasing the high flows. 
Table 1. Hydraulic engineering works in the Hailiutu catchment.

\begin{tabular}{|c|c|c|c|c|c|}
\hline No. & Name & $\begin{array}{r}\text { Year of } \\
\text { construction }\end{array}$ & $\begin{array}{r}\text { Elevation } \\
\text { m(a.m.s.l) }\end{array}$ & Type & Water use \\
\hline 1 & Chaicaoba & 1970 & 1072 & Diversion dam & Irrigation for 53 ha crop land \\
\hline 2 & Tuanjie & 1971 & 1218 & Reservoir & $\begin{array}{l}\text { Water supply for power plant; } \\
\text { irrigation for } 33 \text { ha crop land }\end{array}$ \\
\hline 3 & Maluwan & 1972 & 1124 & Diversion dam & Irrigation for 187 ha crop land \\
\hline 4 & Geliugou & 1972 & 1166 & Reservoir & Irrigation for 33 ha crop land \\
\hline 5 & Caojiamao & 1989 & 1184 & Diversion dam & Irrigation for 93 ha crop land \\
\hline 6 & Hongshijiao & 1992 & 1082 & Diversion dam & Irrigation for 113 ha crop land \\
\hline 7 & Shuanghong & 1995 & 1101 & Diversion dam & Irrigation for 100 ha crop land \\
\hline 8 & Wanjialiandu & 1995 & 1043 & Diversion dam & Irrigation for 133 ha crop land \\
\hline 9 & Wujiafang & 1997 & 1150 & Diversion dam & Irrigation for 60 ha crop land \\
\hline 10 & Weijiamao & 2008 & 1130 & Diversion dam & Irrigation for 67 ha crop land \\
\hline
\end{tabular}

Much of the present studies focus on the relations among the changes in climate and their linkage with the streamflow regime. However, the regime shift of the river discharge can also be caused by the human activities, but very often these factors cannot be distinguished (e.g. Uhlenbrook, 2009). Although some studies on climate change, dam regulation, human activities of soil and water conservations, and their effects on the river discharge have been conducted in the Loess Plateau of the Yellow River and its tributaries, no study focused so far on the regime shifts caused by human activities vs. climate controls in the sandy region in the middle section of the Yellow River Basin.

This paper reveals the flow regime shifts by means of detecting changes in annual, monthly, and daily characteristics of the river discharge and connects with changes in climate, water resources development, and land use in the sandy region of the middle section of the Yellow River Basin. The results provide a better understanding of the hydrological response to climate and human activities in a semi-arid area.

\section{Materials and methods}

\subsection{Study area}

The Hailiutu catchment is located in the middle section of the Yellow River Basin in Northwest China. The Hailiutu River is one of the branches of the Wuding River, which is the major tributary of the middle Yellow River (Fig. 1). The total area of the Hailiutu catchment is around $2645 \mathrm{~km}^{2}$. The surface elevation of the Hailiutu catchment ranges from $1020 \mathrm{~m}$ in the southeast to $1480 \mathrm{~m}$ above mean sea level in the northwest. The land surface is characterized by undulating sand dunes, low hills at the northern and western water divide, and an U-shaped river valley in the downstream area. A hydrological station is located at the outlet of the Hailiutu catchment near Hanjiamao village with a mean annual discharge of $2.64 \mathrm{~m}^{3} \mathrm{~s}^{-1}$ for the period 1957-2007. There is one tributary of the Hailiutu River, named Bulang river, which is situated at the middle part of the catchment. There are two reservoirs constructed; one at the upstream of the Hailiutu River and the other one at the Bulang tributary for local water supply. The information on the construction of the reservoirs and water diversions is listed in the Table 1.

Geographically, the Hailiutu catchment is a part of the Maowusu semi-desert. However, the catchment is mainly covered by xeric shrubland (Fig. 2), which occupies around $88 \%$ of the surface area (Table 2 ). The crop land mixed with wind-breaking trees occupies only $3 \%$ of the total surface area. Most crop lands are located in the river valley and in the Bulang sub-catchment. Grassland areas can be found in local depressions where groundwater is near to the surface. The catchment is characterized by a semi-arid continental climate. The long-term annual average of daily mean temperature from 1961 to 2006 is $8.1^{\circ} \mathrm{C}$ with the highest daily mean temperature of $38.6^{\circ} \mathrm{C}$ recorded in 1935 and the lowest value of $-32.7^{\circ} \mathrm{C}$ observed in 1954 . The monthly mean daily air temperature is below zero in the winter time from November until March (Fig. 3a). The growing season starts in April and lasts until October. The mean value of the annual sunshine hours is $2926 \mathrm{~h}$ (Xu et al., 2009). The mean annual precipitation for the period 1985 to 2008 is $340 \mathrm{~mm} \mathrm{a}^{-1}$, the maximum annual precipitation at Wushenqi is $616.3 \mathrm{~mm} \mathrm{a}^{-1}$ in 2002 , and the minimum annual precipitation is $164.3 \mathrm{~mm} \mathrm{a}^{-1}$ in 1999 (Wushenqi meteorological station monitoring data, 1985-2008). Majority of precipitation occurs in June, July, August and September (Fig. 3b). The mean annual pan evaporation (recorded from evaporation pan with a diameter of $20 \mathrm{~cm}$ ) is $2184 \mathrm{~mm} \mathrm{a}^{-1}$ (Wushenqi metrological station, 1985-2004). The monthly pan evaporation significantly increases from April, reaches highest in May to July, and decreases from August (Fig. 3c). The mean monthly discharges at Hanjiamao station vary from $0.86 \mathrm{~m}^{3} \mathrm{~s}^{-1}$ in April to $11.6 \mathrm{~m}^{3} \mathrm{~s}^{-1}$ in August (Fig. 3d). 


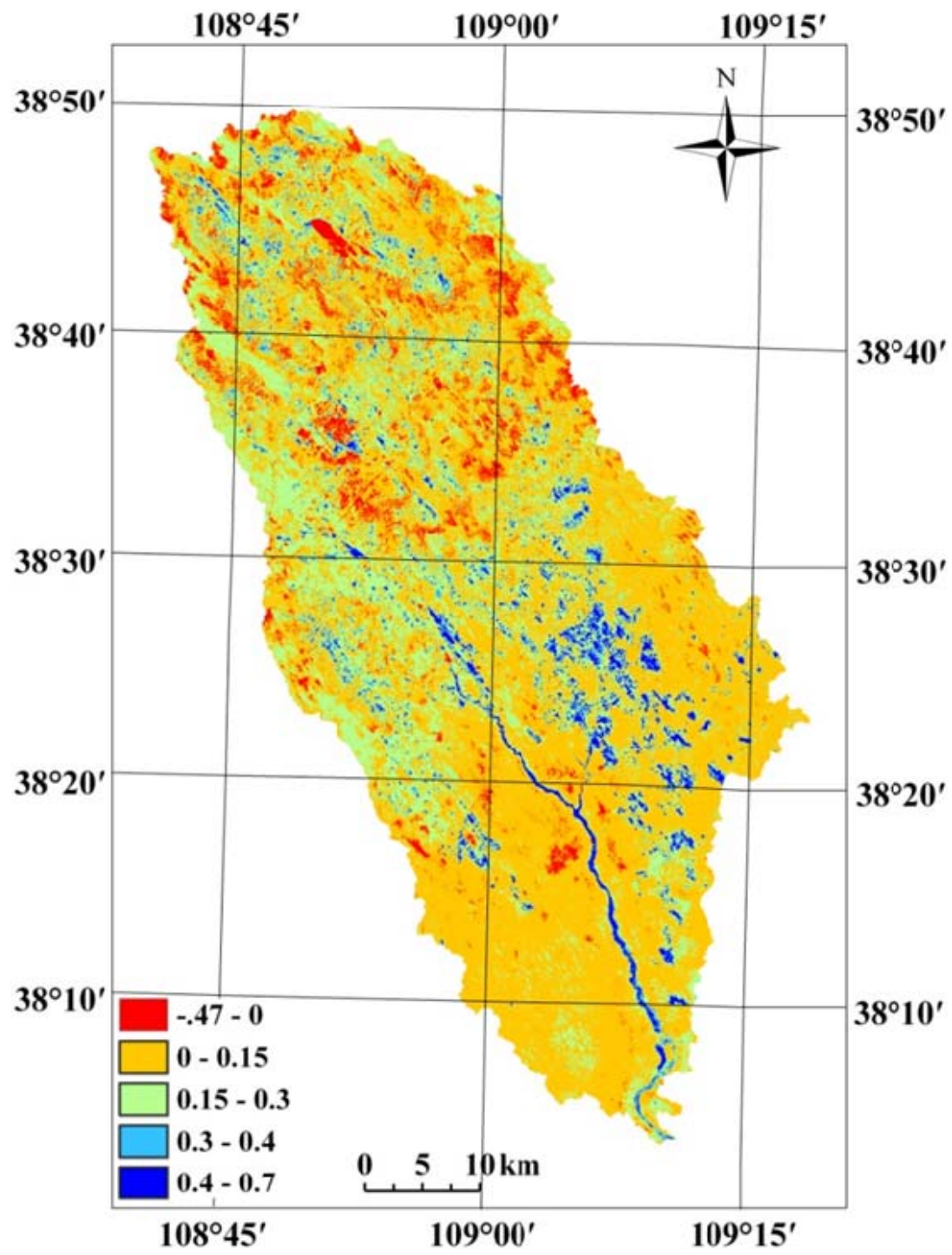

Fig. 2. NDVI map of the Hailiutu catchment, interpretation of remote sensing data from TM image, observed on August 2008; see Table 2 for the conversion of NDVI values to land cover classes.

\subsection{Data}

There are four meteorological stations situated in and around the Hailiutu catchment (Fig. 1), and one hydrological station with daily discharge measurements from 1957 to 2007 at the outlet of the catchment. Daily precipitation at meteorological stations, air temperature from 1961 to 2006 at Yulin and Hengshan, monthly pan evaporation from 1978 to 2004 at Yulin, and monthly pan evaporation from 1985 to 2008 at Wushenqi were collected for analyses (Table 3). Four characteristic time series were derived from daily river discharge series for flow regime shift detection. Annual mean discharge is the average of daily discharges in each year, which is used to analyze changes in mean flows. Annual maximum discharge is the maximum daily discharge in every year, which is used to analyze the changes in peak flows. Annual mean monthly minimum discharge is the average of minimum daily flow of 12 months in every year, and is used to analyze changes in low flows. Annual mean monthly standard deviation is the average of standard deviations of daily discharges in every month, and is used to analyze the variation in monthly mean flows. The climatic variables such as annual precipitation, annual total heavy precipitation (daily rainfall $>10 \mathrm{~mm} \mathrm{~d}^{-1}$ ), number of days of heavy rainfall, average air temperature in the growing season from April to October, and annual pan evaporation were analyzed for possible climate changes. The crop area data from 1949 to 2007 was collected in the Yuyang district, a part of which is located in the Hailiutu catchment. The crop area is an indicator of land use change and the related water use for irrigation. The 
Table 2. Land cover in Hailiutu catchment.

\begin{tabular}{lrrr}
\hline Land cover & NDVI & Area $\left(\mathrm{km}^{2}\right)$ & Percent \\
\hline Bare soil or constructed area & $\leq 0$ & 148 & 5.6 \\
Low density shrubland & $0<\mathrm{NDVI} \leq 0.15$ & 1656 & 62.6 \\
High density shrubland & $0.15<\mathrm{NDVI} \leq 0.3$ & 669 & 25.3 \\
Grassland & $0.3<\mathrm{NDVI} \leq 0.4$ & 90 & 3.4 \\
Crop land and trees & $0.4<\mathrm{NDVI} \leq 0.7$ & 82 & 3.1 \\
\hline Total & & 2645 & 100 \\
\hline
\end{tabular}

amount of river water diversion and groundwater extraction rates was not measured and recorded; thus were not available for analysis.

\subsection{Methods of regime shift detection}

Among all the methods of detection of the regime shifts or the change points, detection of shifts in the means is the most common type (Rodionov, 2005). In this paper, the Pettitt test (Pettitt, 1979), cumulative sum chart (CUSUM) with bootstrap analysis (Taylor, 2000a, b), regime shift index (RSI) calculated by a sequential algorithm of the partial CUSUM method combined with the t-test (Rodionov, 2004) were applied for detecting the shifts in the means of hydrological and climatic variables and crop areas.

The Pettitt test is a non-parametric trend test for identification of a single change point in the time series data, which is often used to detect abrupt changes in hydrological series (e.g. Love et al., 2010). The tests were carried out by the software Datascreen (Dahmen and Hall, 1990) at a probability threshold of $p=0.8$. The time series data were manually divided into sub-series in order to detect the change points in different periods. Abu-Taleb et al. (2007) used the CUSUM and bootstrap analysis for examining annual and seasonal relative humidity variations in Jordan, which begins with the construction of the CUSUM chart for the data sets, then calculates the confidence level by performing a bootstrap analysis for the apparent changes. A sudden change in the direction of the CUSUM indicates a sudden shift in the average. Rodionov (2004) proposed a sequential algorithm that allows for early detection of a regime shift and subsequent monitoring of changes in its magnitude over time. Start with initial subdivision of the data at certain point with the predefined cut-off length, the RSI method estimates the regime shift by statistically testing the means of the previous subsets and subsequent data sets. Then continuously increases the number of the subsequent data sets and recalculates the means until the difference in the means is statistically significant. The regime shift point is identified when the means are statistically different. This point is considered as a possible starting point of the new regime. Among the methods introduced above, the Pettitt test is widely used for examining the occurrence of a single change point in the time series, while multiple change points can be detected by CUSUM and RSI methods. In this study, these three methods were used to detect the regime shifts. A change point is accepted only, if at least two methods detected the same point. Furthermore, in order to verify this change point, the Student t-test in difference in two means was used to ascertain that the mean in the sub-set before the change point and the mean in the sub-set after the change point are statistically significantly different. The periodic characteristics of hydrological variables can be analyzed by harmonic series (Zhou, 1996). Harmonic analyses for monthly discharges and standard deviations of the discharge were applied for different periods based on the preliminary analyses of the flow regime shift. The periodicity, magnitude and phase shift of the harmonic components were investigated in order to detect shifts in the periodic characteristics. Finally, flow duration curves (FDC) of different periods were constructed for investigating the changes of daily discharge characteristics.

\section{Detection of regime shifts}

\subsection{River flow regime changes}

\subsubsection{Change point detection}

The change points for flow regime shifts in 4 characteristic river flow series were detected and are listed in Table 4. Figure 4 presents the detection results of flow regime shifts with the characteristic series (solid line curve) and their step trends (dashed line). Four change points were detected in the annual mean discharge, these changes occur in 1968, 1986, 1992 and 2001. Three change points were detected in the annual maximum discharge: 1971, 1988 and 2000. The annual mean monthly minimum discharge had four change points in 1965, 1985, 1991 and 1998. Finally, the annual mean monthly standard deviation had three change points in 1971, 1990 and 2000. The change points of the annual mean monthly standard deviation are corresponding well to the annual maximum discharge, while the change points in the 
Table 3. List of available data in the research catchment.

\begin{tabular}{llll}
\hline Type & Name & $\begin{array}{r}\text { Elevation } \\
\text { m (a.m.s.l) }\end{array}$ & Data information \\
\hline \multirow{2}{*}{ Hydrological station } & Hanjiamao & 1037 & $\begin{array}{l}\text { daily discharge from 1957 to 2007; daily river stage } \\
(1958 \sim 1960 ; 1963 \sim 1966 ; 1979 \sim 1981 ; 1991 \sim 1997 ; 2000)\end{array}$ \\
\hline \multirow{3}{*}{ Meteorological stations } & Hanjiamao & 1037 & daily rainfall in 1961-1963; 1970-2007 \\
& Henan & 1247 & monthly rainfall and pan evaporation 1985-2004 \\
& Hengshan & 1302 & $\begin{array}{l}\text { monthly rainfall and pan evaporation 1985-2008 } \\
\text { Yulin }\end{array}$ \\
& 1036 & $\begin{array}{l}\text { daily rainfall, relative humid, wind speed, air temperature 1961-2006 } \\
\text { daily rainfall, relative humid, wind speed, air temperature 1961-2006 }\end{array}$ \\
\hline
\end{tabular}

annual mean discharge are caused not only by the maximum and minimum flows, but also the average flow.

\subsubsection{Harmonic analysis}

The harmonic analysis of monthly mean discharge time series shows the distinct periodic characteristics in the identified 5 periods (Table 5). Two discharge peaks occur in every year in the first period from 1957 to 1967: a smaller peak in February-March and a larger peak in August-September (Fig. 5). The small peak in the winter period reflects the maximum groundwater discharge, while the large summer peak resulted from direct rainfall-runoff conversion. In the second period from 1968 to 1985 , the winter peak is shifted one month earlier to January-February, while the summer peak is delayed by one month to October (Table 5). The magnitude of the summer peak became smaller than the winter peak, which is a clear indication of effects of the reservoirs and water diversions on the monthly flow regime. The summer peak disappears in the third period from 1986 to 1991, resulting in only annual periodic fluctuation with the peak flow occurring in November-January produced by groundwater discharge. The monthly flow regime in the fourth period from 1992 to 2000 resembles the third period. However, the amplitude of the variation is much smaller, which indicates increased irrigation water consumption by water diversions from the river and groundwater extraction. The amplitude of the annual periodic fluctuation is increased due to the increase of groundwater discharge in November to January in the fifth period from 2001 to 2007.

Three change points were detected in mean monthly standard deviation series, which, therefore, was divided into 4 periods. There are two peaks in mean monthly standard deviation of discharge time series in the first period from 1957 to 1970, one peak occur in February and another in August (Fig. 5). The amplitude of the peak in August is very large indicating large discharge variations during the summer rainy season. Only one 12-month periodicity with an amplitude of $0.39 \mathrm{~m}^{3} \mathrm{~s}^{-1}$ and peak in July was found in second period from 1971 to 1989 . The similar harmonic characteristics were found in the third period from 1990 to 1999 except for a smaller amplitude of $0.15 \mathrm{~m}^{3} \mathrm{~s}^{-1}$. The variations of river discharges were substantially reduced in these two periods. The fourth period from 2000 to 2007 shows the similar periodic changes with two harmonics as in the first period; however, the summer peak (in August) is smaller (Fig. 5).

Figure 6 illustrates the flow duration curves (FDCs) in the five different periods in the mean daily flow values. The high flows, median flow, and low flows in the first period from 1957 to 1967 are significantly larger than those in other periods. Less difference were found among the high flows in the second, third, and fifth periods, while the high flow is lowest in the fourth period from 1992 to 2000 . The median flow (50\% value) in the second period of $1968-1985$ is the second largest value among the medians in different FDCs, while the median flow in the fourth period 1992-2000 is lowest. The low flows in five periods show a similar pattern as the medians.

\subsection{Past climate and land use changes}

The correlation coefficients among monthly precipitation at four meteorological stations are more than 0.83 (Table 6). The correlation coefficients between annual pan evaporation at Yulin and Wushenqi are also higher than 0.78. The correlation coefficient between the annual average air temperature at Yulin and Hengshan is 0.98. The high correlation coefficients indicate that the annual precipitation, pan evaporation, and air temperature at the meteorological stations are spatially homogeneous and consistent.

The results of regime shift detection of climate variables and crop area in Hailiutu catchment are shown in Table 7 and Fig. 7. No significant shifts were found in the annual precipitation, total heavy precipitation (daily rainfall $>10 \mathrm{~mm} \mathrm{~d}^{-1}$ ), number of days of the heavy precipitation, and pan evaporation time series by all three methods. Since the temperature from November until March is below zero, ground freezes in winter season. There are also no ever-green plants in the catchment. Thus evaporation can be assumed zero in winter season. The growing season starts from April and ends 

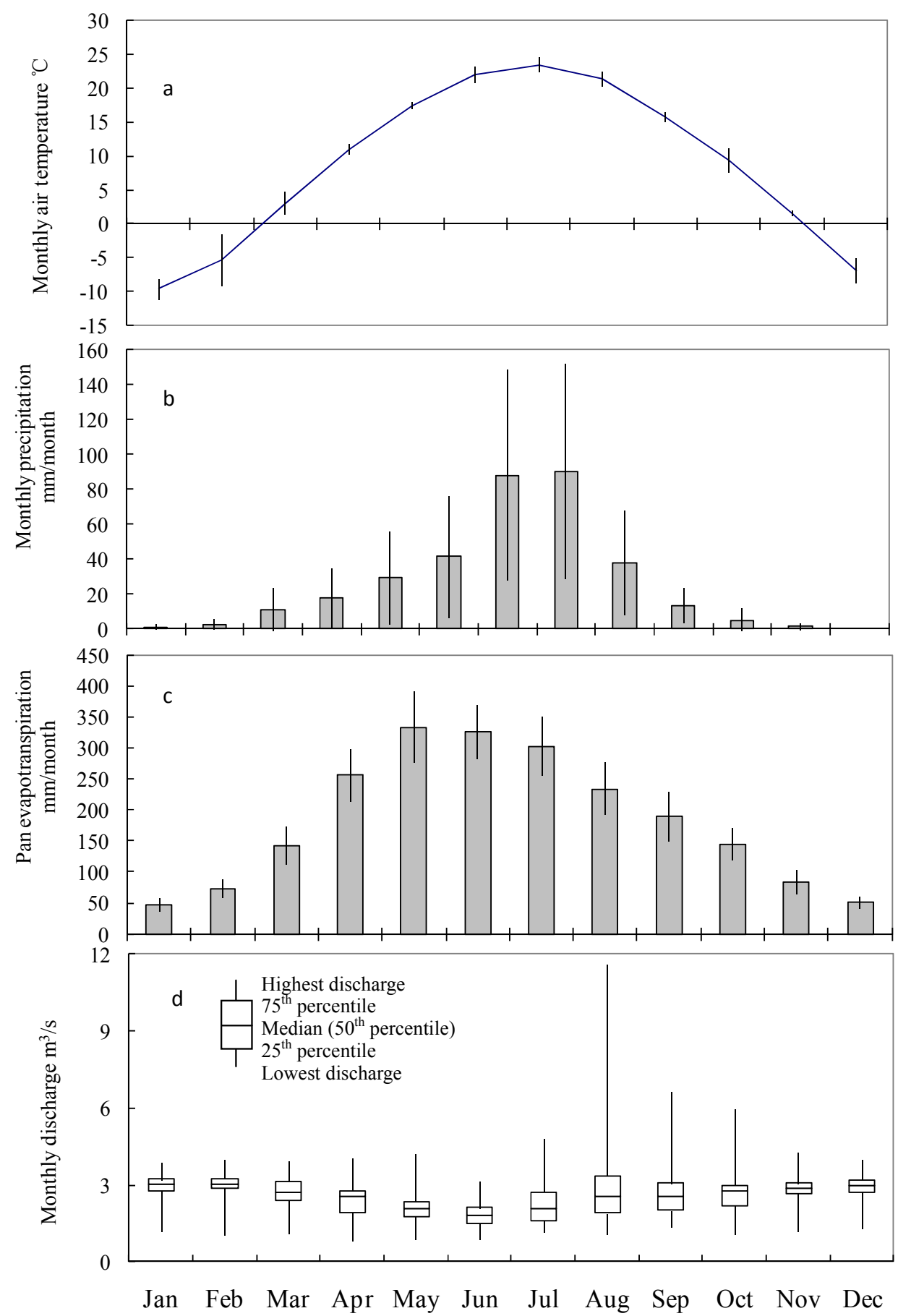

Fig. 3. (a) Mean monthly air temperature (2005-2008); (b) mean monthly precipitation (1984-2005); (c) mean monthly pan evaporation (1984-2005) at Wushenqi meteorological station; and (d) mean monthly discharge at Hanjiamao station (1957-2007), the error bars indicate the standard deviations for precipitation, potential evaporation, air temperature and the percentiles of the discharge.

in October in this region. The temperature in the growing season has impact on actual evaporation. Therefore, average temperature in growing season (from Aril to October) was used for the detection of temperature changes. A significant increase in the average temperature in the growing season was detected at 1997 at Yulin and Hengshan meteorological stations. Three change points of crop area were detected at 1971, 1990, and 1999. The crop area was decreased by $7 \%$ from the period of $1957-1970$ to the period of 19711989. The crop area was increased by $15 \%$ from the period 
Table 4. List of available data in the research catchment.

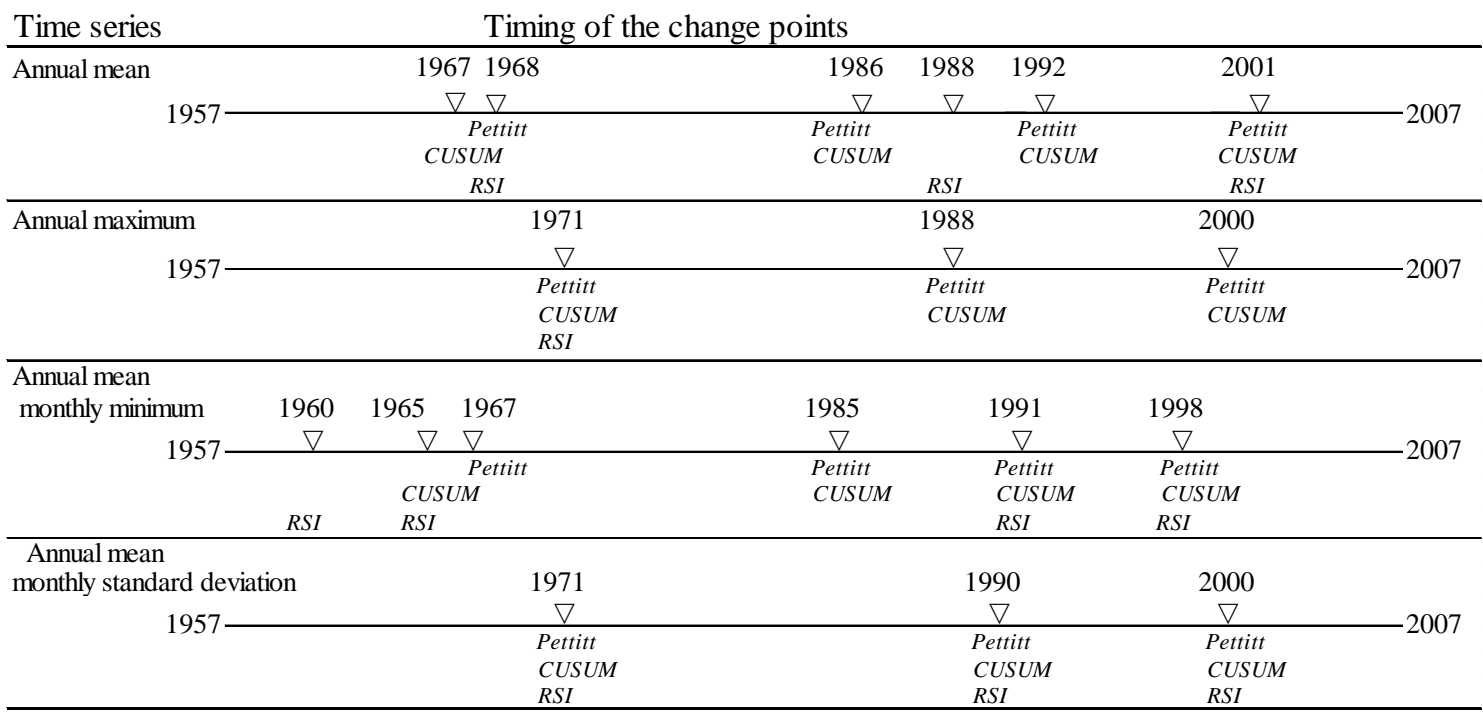

The black line represents the time from 1957 to 2007, the triangle symbols above the time line stand for change points detected at the year, the detection methods for the change points are summarized below the time line.

Table 5. Harmonic characteristics of monthly discharge and standard deviation at Hanjiamao station.

\begin{tabular}{lrrrrr}
\hline Monthly mean & $1957-1967$ & $1968-1985$ & $1986-1991$ & $1992-2000$ & $2001-2007$ \\
\hline Periodicity (month) & 6 & $12 / 6$ & 12 & 12 & 12 \\
Amplitude & 0.52 & $0.47 / 0.26$ & 0.58 & 0.35 & 0.71 \\
Peak discharge occurs in & Feb-Mar/Aug-Sep & Jan-Feb/Oct & Dec-Jan & Dec-Jan & Dec-Jan \\
\hline Standard deviation & $1957-1970$ & $1971-1989$ & $1990-1999$ & $2000-2007$ \\
\hline Periodicity (month) & $12 / 6$ & 12 & & 12 & $12 / 6$ \\
Amplitude & $0.80 / 0.44$ & 0.39 & 0.15 & $0.46 / 0.25$ \\
Peak discharge occurs in & Feb/Aug & Jul & & Jul & Feb/Aug \\
\hline
\end{tabular}

Table 6. Correlation coefficients of monthly precipitation at meteorological stations.

\begin{tabular}{lrrrr}
\hline $\begin{array}{l}\text { Correlation } \\
\text { coefficients }\end{array}$ & $P_{\text {Yulin }}$ & $P_{\text {Wushenqi }}$ & $P_{\text {Henan }}$ & $P_{\text {Hengshan }}$ \\
\hline$P_{\text {Yulin }}$ & 1 & & & \\
$P_{\text {Wushenqi }}$ & 0.89 & 1 & & \\
$P_{\text {Henan }}$ & 0.88 & 0.84 & 1 & 1 \\
$P_{\text {Hengshan }}$ & 0.89 & 0.83 & 0.95 & 1 \\
\hline
\end{tabular}

of 1971-1989 to the period of 1990-1998. The crop area in the last period of 1999-2007 was decreased by $17 \%$ from the previous period.

\section{Analysis of the results}

\subsection{Characteristics of flow regime changes over time}

According to the change point detection results, the annual mean flow regime at Hanjiamao station from 1957 to 2007 can be divided into 5 distinctive periods. The flow regime in the first period from 1957 to 1967 represents quasi natural variations with a mean discharge value of $3.49 \mathrm{~m}^{3} \mathrm{~s}^{-1}$, a 6 month periodicity, and the comparable high daily discharges. Two peaks in monthly mean discharge series reflect a small discharge peak in winter with maximum baseflow from groundwater discharge and a large discharge peak in summer originating from seasonal rainfall. In the second period from 1968 to 1985 , the flow regime can be characterized by a lower mean discharge value of $2.72 \mathrm{~m}^{3} \mathrm{~s}^{-1}$, 12 and 6 month periodicities, and lower daily flows, which implies that the discharge had been affected. In the third 

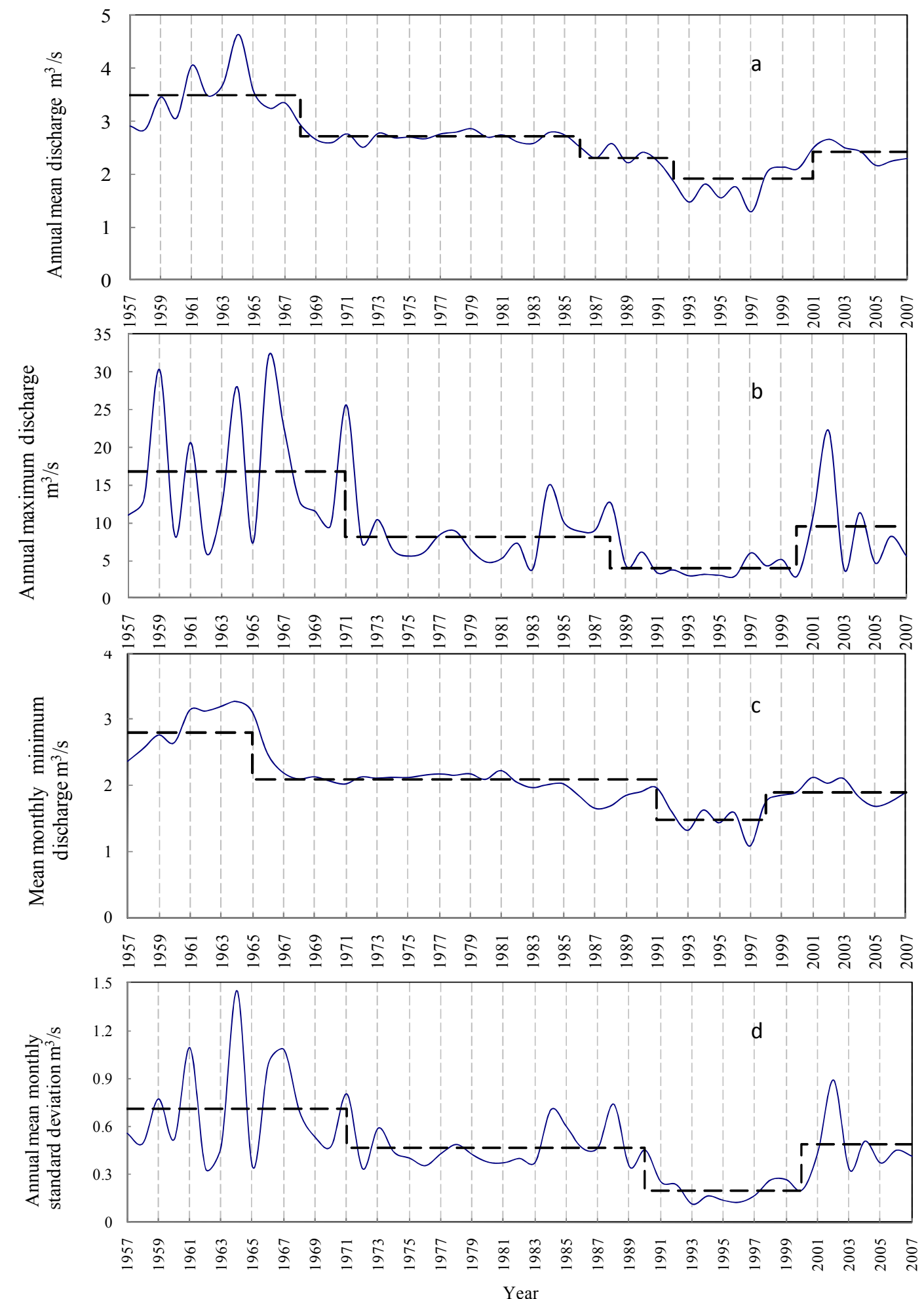

Fig. 4. Flow regime shifts in the annual mean discharge (a), annual maximum discharge (b), annual mean monthly minimum discharge (c), and the annual mean monthly standard deviation (d) at Hanjiamao station from 1957 to 2007, the solid lines are the characteristic series and the dashed lines are the their step trends. 


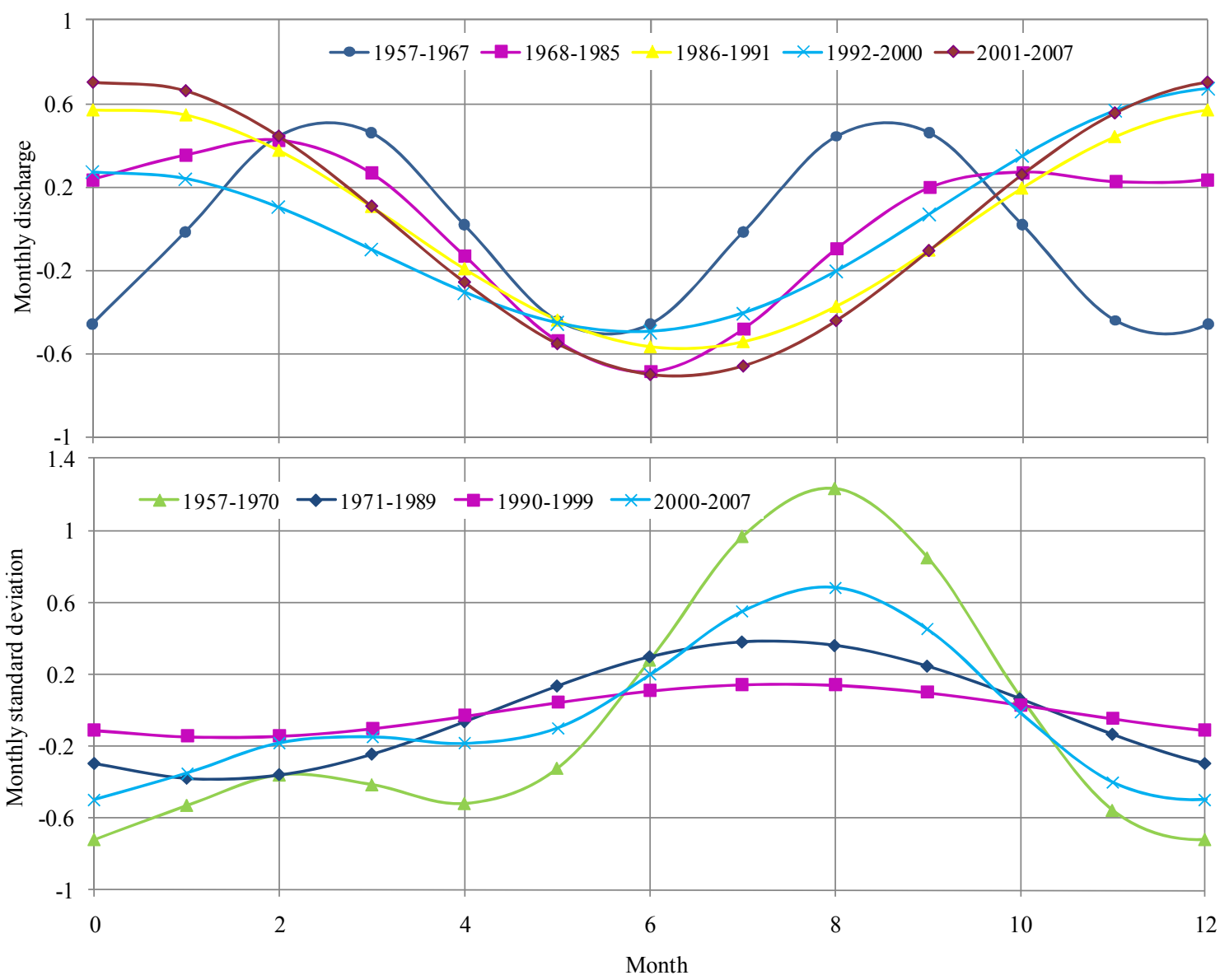

Fig. 5. Harmonic changes in monthly mean discharge and standard deviation at Hanjiamao station for different periods.

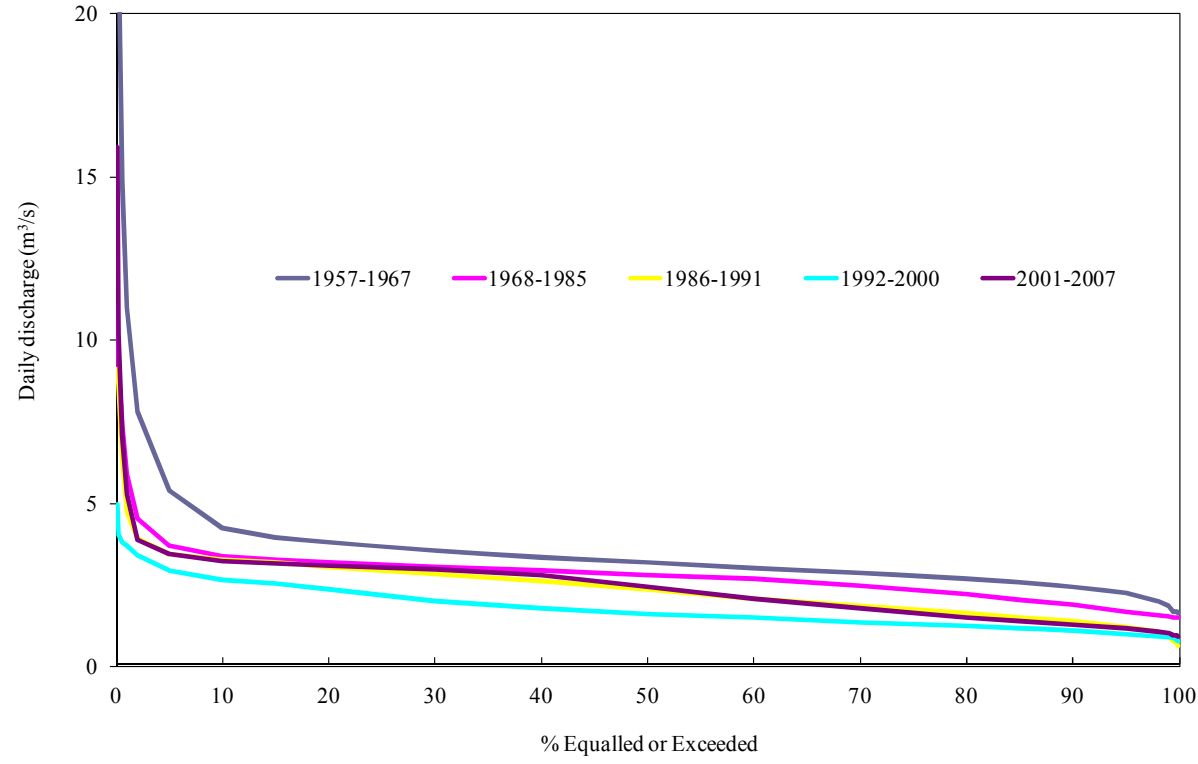

Fig. 6. Flow duration curves for mean daily discharges at Hanjiamao station in the 5 different periods. 

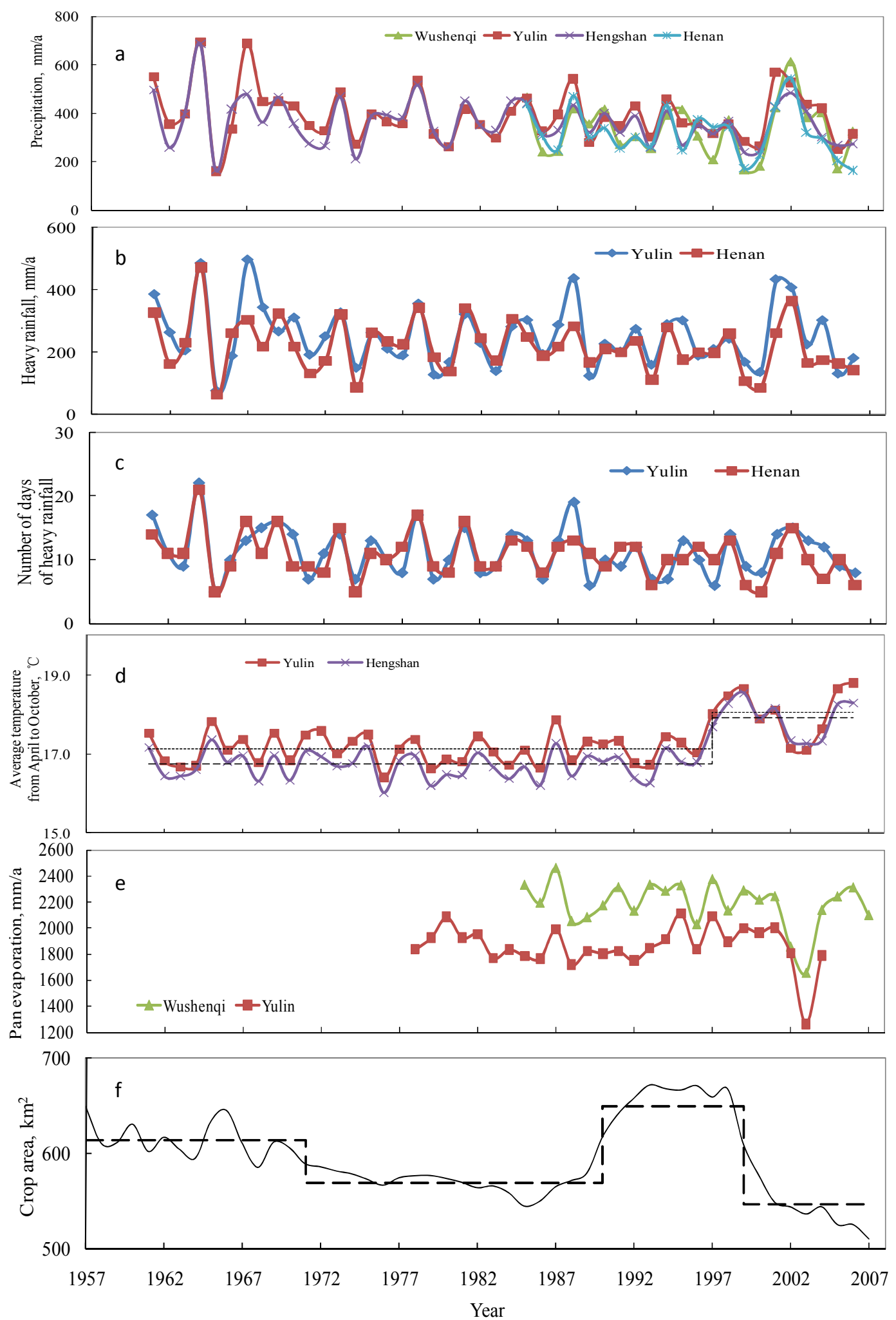

Fig. 7. Annual precipitation (a), Heavy precipitation $\left(>10 \mathrm{~mm} \mathrm{~d}^{-1}\right)(\mathbf{b})$, number of days of heavy precipitation (c), annual mean temperature from April to October (d) at meteorological stations from 1961 to 2006. Annual pan evaporation (e) and annual crop area (f) in Yuyang district from 1957 to 2007, the dashed lines are the step trends. 
Table 7. Regime shift detection results of climate variables and crop area.

\begin{tabular}{|c|c|c|c|}
\hline \multirow{3}{*}{\multicolumn{2}{|c|}{$\frac{\text { Time series }}{\text { Average temperature from April to October at Yulin }}$}} & & \\
\hline & & & \\
\hline & & 1985 & 1997 \\
\hline & \multirow{4}{*}{ 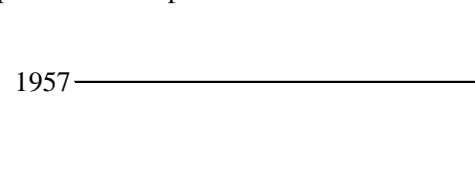 } & $\nabla$ & $\nabla$ \\
\hline & & Pettitt & Pettitt \\
\hline & & & CUSUM \\
\hline & & & RSI \\
\hline \multicolumn{4}{|c|}{ Average temperature from April to October at Hengshan } \\
\hline & \multirow{5}{*}{$1957-$} & 1985 & 1997 \\
\hline & & $\nabla$ & $\nabla$ \\
\hline & & Pettitt & Pettitt \\
\hline & & & CUSUM \\
\hline & & & RSI \\
\hline \multicolumn{4}{|c|}{ Crop area in Yuyang } \\
\hline & 19701971 & 19901991 & 1999 \\
\hline & 1957 & $\nabla \nabla$ & $\nabla$ \\
\hline & $1957-$ & Pettitt & Pettitt \\
\hline & CUSUM & CUSUM & CUSUM \\
\hline & RSI & $R S I$ & RSI \\
\hline
\end{tabular}

The black line represents the time from 1957 to 2007, the triangle symbols above the time line stand for change points detected at the year, the detection methods for the change points are summarized below the time line.

period of 1986-1991, the mean discharge further decreased to $2.3 \mathrm{~m}^{3} \mathrm{~s}^{-1}$. The magnitude of the summer peak discharge became smaller than the winter peak. The daily flows continuously declined in the fourth period of 1992-2000. The discharge reached lowest levels with a mean value of $1.92 \mathrm{~m}^{3} \mathrm{~s}^{-1}$, lowest amplitude of harmonic components, and lowest daily flows. The discharge recovered comparably to the previous but not yet to the natural level in the fifth period of 2001-2007 with a mean value of $2.41 \mathrm{~m}^{3} \mathrm{~s}^{-1}, 12$ month periodicity, and comparable higher daily flows.

\subsection{Causes of flow regime shifts}

The climatic variables such as precipitation, pan evaporation, and the human activities are normally correlated with the observed discharge variability. Hu et al. (2011b) analyzed trends in temperature and rainfall extremes from 16 meteorological stations in the Yellow River source region. They found significant warming trends in the whole source area, but no significant changes in the annual rainfall for the majority of the stations except in the upper part of the region. Thus, the decrease of the stream flow in the source region of the Yellow River can be ascribed to the increase of temperature resulting in higher evaporation losses. In this study, no significant changes in the annual precipitation, the heavy rainfall (daily rainfall $>10 \mathrm{~mm} \mathrm{~d}^{-1}$ ), and the number of heavy rainfall days, were detected. There are no significant changes detected in pan evaporation rates. The change point detection methods indentified an increase of average growing-season temperature since 1997. This temperature increase could also have an impact on the decrease of river flows since the actual evaporation was expected to increase with a higher temperature. On the contrary, river flow has increased since 2001. The main cause was the significant decrease of crop area with the implementation of the policy to return farmland to forest and grassland that started in 1999. In the study catchment, crop area in large parts returned to the natural vegetation cover, which consists of desert bushes. Actual evaporation from desert bushes is much smaller than from irrigated cropland under a higher temperature. The decrease of net water use because of large decrease in crop area had much larger impact on the river flow than a possible increase of actual evaporation from desert bushes under higher temperature. This explains why river flows have increased in spite of the temperature increase. Therefore, the flow regime shifts in the Hailiutu River were not likely caused by climatic changes.

Figure 8 connects the local/regional land policies with the changes in crop area and observed flow regime shifts in Hailiutu River. The changes of crop area in Yuyang district can represent the changes in the amount of water diverted from river and groundwater exploitation for irrigation. The crop area has been influenced by the policy for cultivation and agriculture during the last $51 \mathrm{yr}$ (Fig. 8). The crop area remained at a certain level from 1957 to 1970 when the crop land development and degradation processes were balanced. The crop area gradually decreased from early 1970's when the cultivated land was converted to terraces for agriculture with the policy of emulating Dazhai on agriculture campaign (Bi and Zheng, 2000). The policy of distributing the cultivated land to farmers was implemented in the early 1980's, which eventually stimulated the farmers to enlarge the crop 


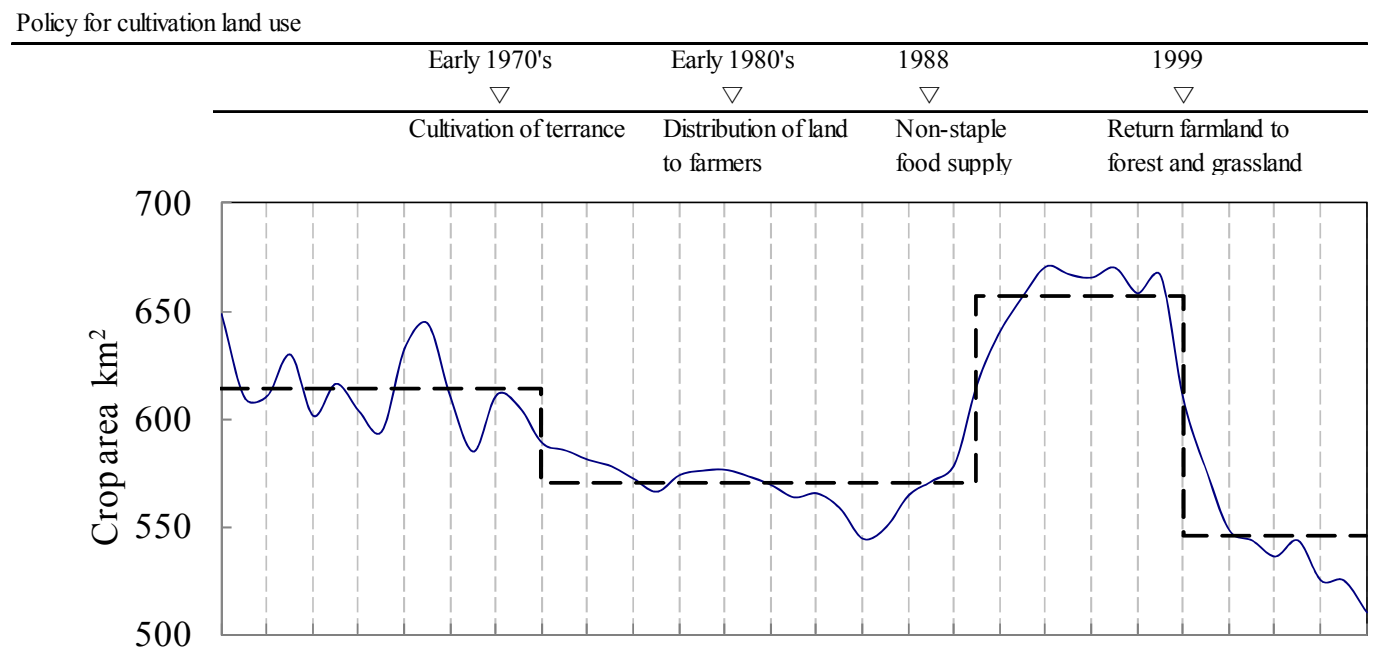

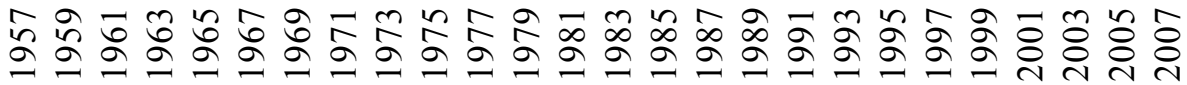

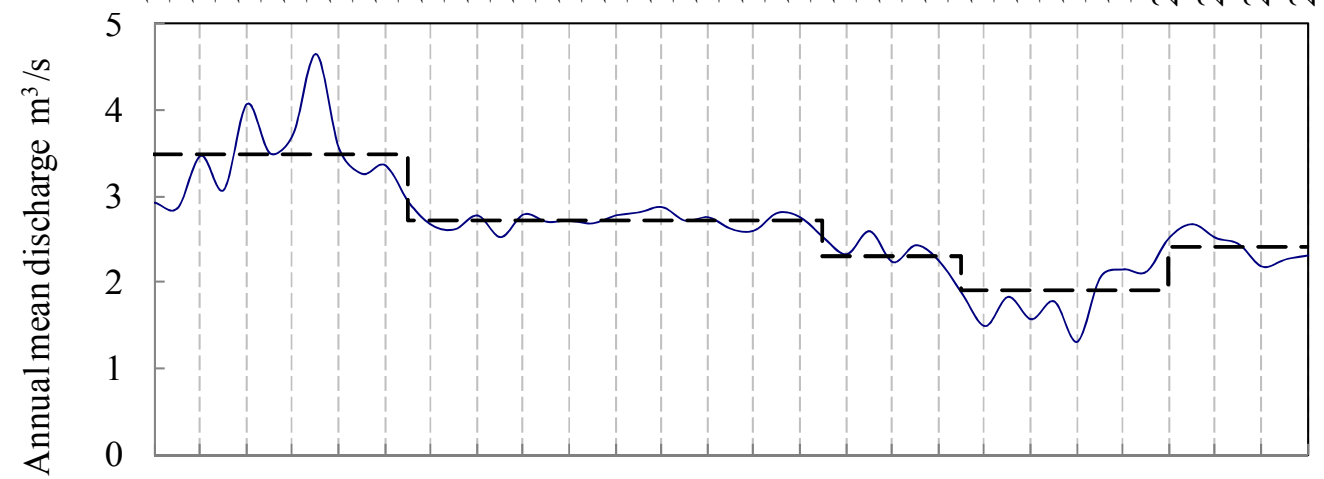

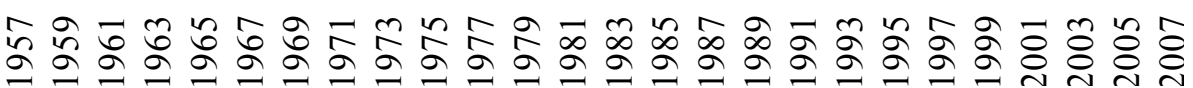

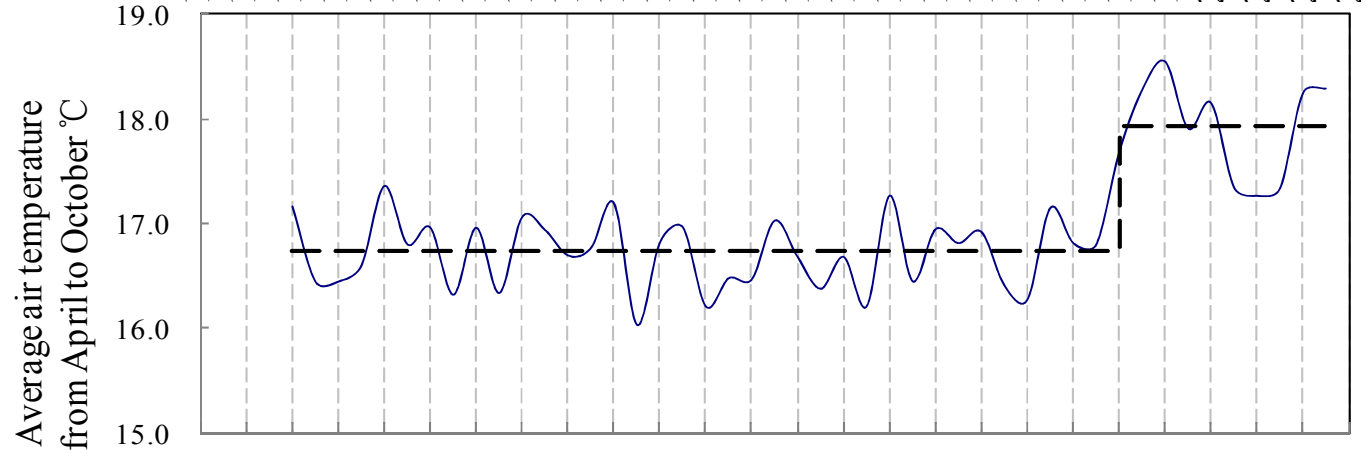

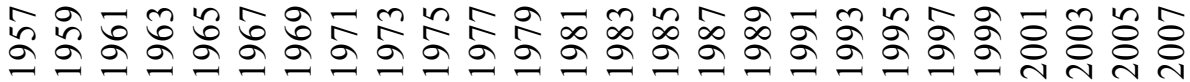

Year

Fig. 8. Illustration of the causes for regime shifts; the cultivation policy, crop area, annual discharge, and temperature form April to October at Yulin meteorological station.

area (Zhang et al., 2009). The crop area was increased during 1990-1998 for the vegetable production according to the policy of non-staple food supply in urban districts in 1988 (Wang and Xu, 2002), which implies that intensive water diversion works and groundwater extraction wells were constructed to secure the irrigation for the crop land. The Chinese government has implemented a program to return the crop land to forest or grassland for ecosystem rehabilitation since 1999 (Li and Lv, 2004), which resulted in a decrease of crop area from 2000 to 2007. Land cover change 
caused by the cultivation policy is related to crop area change in the study area. In the river valley, it is the change between maize and nursery garden for trees. Trees (especially young, fast growing trees) may consume more water, but the area is limited. In the upper part of the catchment, it is the change between maize and desert bushes. Desert bushes (not irrigated) consume much less water compared to irrigated maize. We can conclude that with a large decrease of crop area since 1999 (Fig. 8), actual evaporation was decreased resulting in an increase of river discharge. Although temperature increased in the same period, but the increase of actual evaporation by the temperature increase was much less than the reduction of actual evaporation by the crop area decrease.

The hydraulic works such as reservoirs may significantly retard and reduce surface runoff and, hence, are expected to have great impact on the discharge variability and particularly on the annual maximum streamflow ( $\mathrm{Li}$ et al., 2007). The change point in the annual maximum discharge was detected at 1971 when the two reservoirs were constructed in the main river and tributary. In the subsequent period of 1971-1984, the standard deviation decreased due to the combined effects from the reservoirs and groundwater exploitation. The maximum discharge and standard deviation were slightly increased in the period of 1985-1990 when less operation of the hydraulic engineering works during the initial stage of policy that the farmers could cultivate individually (Zhang et al., 2009). In the fourth period of 1990-1999, the maximum discharges are lowest due to the combined effects of reservoirs and construction of several water diversions for irrigation. The increase of maximum discharge and the standard deviation in the fifth period indicate a reduction of water diversion.

The low flows during the dry season are sensitive to changes in the groundwater system because the groundwater discharge dominates in the dry season. The groundwater abstractions started in the 1970's based on the analysis of annual mean monthly minimum discharge. The intensive groundwater exploitation is responsible for the lowest minimum discharge in the period of 1992-2000. The increase of the minimum discharge in the fifth period indicates a possible reduction of groundwater extraction.

\subsection{Regression analysis}

The lack of historical data on river water diversions, groundwater abstractions, detailed land cover changes and actual evaporation prevent a full quantitative cause-effect analysis. Nevertheless, the simple regression analysis of annual mean discharge against annual precipitation, crop area and annual average air temperature in growing season was performed to get insight on their cause-effect relations. Based on the results of detection for flow regime shifts, the flow regime has been disturbed since 1968. The annual mean discharge at the Hanjiamao station, annual precipitation and air temperature in growing season at the Yulin station, and crop area
Table 8. Correlation coefficients among discharge, precipitation, air temperature in growing season, and crop area from 1968 to 2006.

\begin{tabular}{lrrrr}
\hline & $Q\left(\mathrm{~mm} \mathrm{a}^{-1}\right)$ & $P\left(\mathrm{~mm} \mathrm{a}^{-1}\right)$ & $A_{\text {crop }}\left(\mathrm{km}^{2}\right)$ & $T\left({ }^{\circ} \mathrm{C}\right)$ \\
\hline$Q\left(\mathrm{~mm} \mathrm{a}^{-1}\right)$ & 1.00 & & & \\
$P\left(\mathrm{~mm} \mathrm{a}^{-1}\right)$ & 0.42 & 1.00 & & \\
$A_{\text {crop }}\left(\mathrm{km}^{2}\right)$ & -0.71 & -0.40 & 1.00 & \\
$T\left({ }^{\circ} \mathrm{C}\right)$ & -0.33 & -0.21 & -0.05 & 1.00 \\
\hline
\end{tabular}

$Q$ is the annual mean discharge at Hanjiamao station, $P$ and $T$ are the annual precipitation and temperature in growing season at Yulin station, $A_{\text {crop }}$ is crop area in Yuyang district.

in Yuyang district from 1968 to 2006 were selected for the analysis. Table 8 shows the correlation coefficients among the variables. It is clear that the annual mean discharge is positively dependent of the precipitation, but negatively dependent of crop area and air temperature. It can further be seen that the correlation coefficient between river discharge and crop area is much larger than those of precipitation or temperature.

The regression equation among the discharge, precipitation, air temperature in growing season, and crop area was found as follows:

$Q=124.8+0.004 \times P-2.904 \times T-0.079 \times A_{\text {crop }}$

Where the $Q$ is the annual mean discharge in $\mathrm{mm} \mathrm{a}^{-1}, P$ is annual precipitation in $\mathrm{mm} \mathrm{a}^{-1}, T$ is annual average temperature in ${ }^{\circ} \mathrm{C}$, and $A_{\text {crop }}$ is the crop area in $\mathrm{km}^{2}$. The multiple regression analysis (Fig. 9) yielded a coefficient of determination of 0.64 , indicating that $64 \%$ of the variation in the annual mean discharge can be explained by the combined variation of the precipitation, crop area and temperature in growing season. With an increase of crop area or temperature, river discharge decreases since the actual evaporation increases with the increased temperature or crop area. The regression could be likely improved if the actual data of water diversion and groundwater extraction would be available.

\section{Conclusions}

The flow regime shift detection and harmonic analysis show that the flow regime of the Hailiutu River has been changed dramatically over the last 51 yr. Four major shifts in the flow regime have been detected in 1968, 1986, 1992 and 2001. The first period from 1957 to 1967 represents in general the natural variation of the river flow with higher annual mean discharge, large annual maximum discharge, large standard deviation of mean monthly discharges, 6-month periodicity of two flow peaks (one in winter and one in summer) per year, and the high daily flow variability. The flow regime is modified in the second period from 1968 to 1985 mainly by the construction of reservoirs and water diversion works, which resulted in lower annual mean discharge, significant 


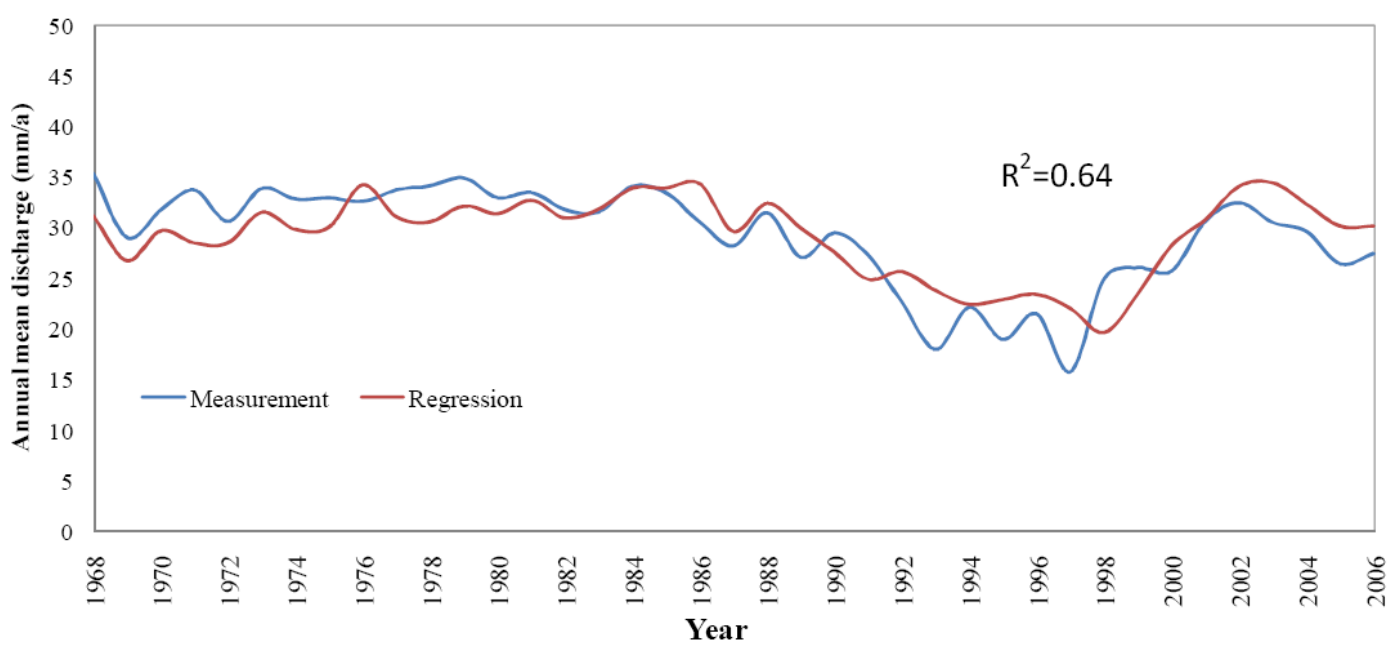

Fig. 9. Fit of prediction by multiple regression of the annual mean discharge at Hanjiamao station with the climatic variables at Yulin station and crop area in Yuyang district from 1968 to 2006.

reduction of summer flow peak, smaller standard deviation of mean monthly discharges, and low daily flows. In the third period of 1986-1991, the discharge continuously decreased due to the combined impacts by the river water diversion and the increase of the groundwater extraction. The summer flow peak is vanished because of river water diversion, leaving only the winter flow peak formed by groundwater discharge. The winter flow peak is shifted one month earlier possibly due to the irrigation return flow in the river valley, which still needs to be investigated. The annual mean discharge, annual maximum discharge, and the annual average standard deviation of mean monthly discharge were lowest in the fourth period of 1992-2000 due to a large increase of crop land with intensive water diversion and groundwater extraction for irrigation. The flow rate and variation recovered, but not yet to natural levels in the fifth period of 2001-2007, which can be attributed to the decrease of water extraction as a result of the implementation of the policy of returning farmland to forest and grassland in the catchment. In the study catchment, the policy of return farmland to forest and grassland means to convert cropland to natural xeric bushland. The bushland is not irrigated and evaporates less than irrigated cropland, which seems to be the main reason for the streamflow increases from 2001 onwards.

The analyses show that there are no significant climate changes in the Hailiutu River catchment. Only the average air temperature in the growing season (April to October) was increased since 1997, but has not caused significant changes in the flow regime. On the contrary, historical land use policy changes had always had the footprint in the flow regime changes. Reservoirs and river water diversions are the main causes of reduction and disappearance of summer flow peaks. Groundwater extraction for irrigation reduces river base flow and contributes to the decrease of the annual mean discharge.
The simple regression analysis of annual mean discharge against annual precipitation, crop area and average air temperature in growing season indicates that the largest contribution to the variation in river discharges comes from crop area, the combined effects of temperature and precipitation on flow variation is smaller than that of the crop area.

Expansion of the crop area in 1989-1999 not only caused lowest river flow, but the decrease of regional groundwater levels threaten the health of the desert vegetation. The degradation of the desert vegetation ecosystem forced the local government to implement the policy of return farmland to desert vegetation in order to reduce groundwater abstraction for irrigation since 1999. This is the only time in the study catchment that the human policy was changed in response to the hydrological regime change. The positive effects have been observed since 2001: river flow is recovered; vegetation health is improved.

The river flow regime changes might have consequences on riparian ecosystems and downstream water use. The sustainable water resources development and management in the Hailiutu river catchment must consider the interactions of groundwater and river flow, and the consequences on the vegetation and downstream water use. Future research work should analyze effects of groundwater extraction on river flows and groundwater dependent vegetation in the catchment.

Acknowledgements. This study is supported by the Asia Facility for China project "Partnership for research and education in water and ecosystem interactions", the Honor Power Foundation, and the Dutch government. Special thanks to the Yellow River Conservancy Commission for making the data available for this study. The constructive comments by M. Sivapalan and an anonymous reviewer helped to improve the final manuscript.

Edited by: N. Verhoest 


\section{References}

Abu-Taleb, A. A., Alawneh, A. J., and Smadi, M. M.: Statistical analysis of recent changes in relative humidity in Jordan, Am. J. Environ. Sci, 3, 75-77, 2007.

Arnell, N. and Reynard, N.: The effects of climate change due to global warming on river flows in Great Britain, J. Hydrol., 183, 397-424, 1996

Bewket, W. and Sterk, G.: Dynamics in land cover and its effect on stream flow in the Chemoga watershed, Blue Nile basin, Ethiopia, Hydrol. Process., 19, 445-458, 2005.

Bi, Y. Y. and Zheng, Z. Y.: The actual changes of cultivated area since the founding of new China, Resources Science, 22, 8-12, 2000, (in Chinese with English abstract).

Chen, Y., Takeuchi, K., Xu, C. C., and Xu, Z. X.: Regional climate change and its effects on river runoff in the Tarim Basin, China, Hydrol. Process., 20, 2207-2216, 2006.

Chiew, F. H. S. and McMahon, T. A.: Modelling the impacts of climate change on Australian streamflow, Hydrol. Process., 16, 1235-1245, 2002.

Christensen, N. S., Wood, A. W., Voisin, N., Lettenmaier, D. P., and Palmer, R. N.: The effects of climate change on the hydrology and water resources of the Colorado River basin, Climatic Change, 62, 337-363, 2004.

Cognard-Plancq, A. L., Marc, V., Didon-Lescot, J. F., and Normand, M.: The role of forest cover on streamflow down subMediterranean mountain watersheds: a modelling approach, J. Hydrol., 254, 229-243, 2001.

Costa, M. H., Botta, A., and Cardille, J. A.: Effects of large-scale changes in land cover on the discharge of the Tocantins River, Southeastern Amazonia, J. Hydrol., 283, 206-217, 2003.

Dahmen, E. and Hall, M. J.: Screening of hydrological data: tests for stationarity and relative consistency, 49, International Institute for Land Reclamation and Improvement, 1990.

Dou, L., Huang, M. B., and Hong, Y.: Statistical Assessment of the Impact of Conservation Measures on Streamflow Responses in a Watershed of the Loess Plateau, China, Water Resour. Manage., 23, 1935-1949, 2009.

Drogue, G., Pfister, L., Leviandier, T., El Idrissi, A., Iffly, J. F., Matgen, P., Humbert, J., and Hoffmann, L.: Simulating the spatiotemporal variability of streamflow response to climate change scenarios in a mesoscale basin, J. Hydrol., 293, 255-269, 2004.

Eckhardt, K. and Ulbrich, U.: Potential impacts of climate change on groundwater recharge and streamflow in a central European low mountain range, J. Hydrol., 284, 244-252, 2003.

Fohrer, N., Haverkamp, S., Eckhardt, K., and Frede, H. G.: Hydrologic response to land use changes on the catchment scale, Phys. Chem. Earth B, 26, 577-582, 2001.

Fu, G. B., Charles, S. P., Viney, R. N., Chen, S. L., and Wu, J. Q.: Impacts of climate variability on stream flow in the Yellow River, Hydrol. Process., 21, 3431-3439, 2007.

Gellens, D. and Roulin, E.: Streamflow response of Belgian catchments to IPCC climate change scenarios, J. Hydrol., 210, 242$258,1998$.

Guo, H., Hu, Q., and Jiang, T.: Annual and seasonal streamflow responses to climate and land-cover changes in the Poyang Lake basin, China, J. Hydrol., 355, 106-122, 2008.

He, Y. Q., Pu, T., Li, Z. X., Zhu, G. F., Wang, S. J., Zhang, N. N., Wang, S. X., Xin, H. J., Theakstone, W. H., and Du, J. K.: Climate change and its effect on annual runoff in Lijiang Basin-
Mt. Yulong Region, China, Jo. Earth Sci., 21, 137-147, 2010.

Hu, Y., Maskey, S., Uhlenbrook, S., and Zhao, H.: Streamflow trends and climate linkages in the source region of the Yellow River, China, Hydrol. Process., 25, 1099-1085, 2011 a.

$\mathrm{Hu}$, Y., Maskey, S., and Uhlenbrook, S.: Trends in temperature and rainfall extremes in the Yellow River source region, China, Climatic Change, 1-27, doi:10.1007/s10584-011-0056-2, $2011 \mathrm{~b}$.

Jha, M., Pan, Z., Takle, E. S., and Gu, R.: Impacts of climate change on streamflow in the Upper Mississippi River Basin: A regional climate model perspective, J. Geophys. Res., 109, D09105, doi:10.1029/2003JD003686, 2004.

Lavers, D., Prudhomme, C., and Hannah, D. M.: Large-scale climate, precipitation and British river flows: Identifying hydroclimatological connections and dynamics, J. Hydrol., 395, 242255, 2010.

Li, D. H. and Lv, F. Y.: The function and economy of shrub in return farmland to forest and grass plan in Yulin, Shanxi forest, No 13 Green forum, 2004 (in Chinese).

Li, L. J., Zhang, L., Wang, H., Wang, J., Yang, J. W., Jiang, D. J., Li, J. Y., and Qin, D. Y.: Assessing the impact of climate variability and human activities on streamflow from the Wuding River basin in China, Hydrol. Process., 21, 3485-3491, 2007.

Love, D., Uhlenbrook, S., Twomlow, S., and Zaag, P.: Changing hydroclimatic and discharge patterns in the northern Limpopo Basin, Zimbabwe, Water SA (Online), 36, 335-350, 2010.

Magilligan, F. J. and Nislow, K. H.: Changes in hydrologic regime by dams, Geomorphology, 71, 61-78, 2005.

Maheshwari, B., Walker, K. F., and McMahon, T.: Effects of regulation on the flow regime of the River Murray, Australia, Regulated Rivers: Research \& Management, 10, 15-38, 1995.

Masih, I., Uhlenbrook, S., Maskey, S., and Smakhtin, V.: Streamflow trends and climate linkages in the Zagros Mountains, Iran, Climatic Change, 104, 317-338, doi:10.1007/s10584-009-9793$\mathrm{x}, 2011$.

Matheussen, B., Kirschbaum, R. L., Goodman, I. A., O’Donnell, G. M., and Lettenmaier, D. P.: Effects of land cover change on streamflow in the interior Columbia River Basin (USA and Canada), Hydrol. Process., 14, 867-885, 2000.

Middelkoop, H., Daamen, K., Gellens, D., Grabs, W., Kwadijk, J. C. J., Lang, H., Parmet, B. W. A. H., Schädler, B., Schulla, J., and Wilke, K.: Impact of Climate Change on Hydrological Regimes and Water Resources Management in the Rhine Basin, Climatic Change, 49, 105-128, doi:10.1023/a:1010784727448, 2001.

Milliman, J., Farnsworth, K., Jones, P., Xu, K., and Smith, L.: Climatic and anthropogenic factors affecting river discharge to the global ocean, 1951-2000, Global Planet. Change, 62, 187-194, 2008.

Neff, R., Chang, H., Knight, C. G., Najjar, R. G., Yarnal, B., and Walker, H. A.: Impact of climate variation and change on MidAtlantic Region hydrology and water resources, Clim. Res., 14, 207-218, 2000.

Pettitt, A.: A non-parametric approach to the change-point problem, J. R. Stat. Soc. C (Applied Statistics), 28, 126-135, 1979.

Poff, N. L. R., Bledsoe, B. P., and Cuhaciyan, C. O.: Hydrologic variation with land use across the contiguous United States: geomorphic and ecological consequences for stream ecosystems, Geomorphology, 79, 264-285, 2006.

Richter, B. D., Baumgartner, J. V., Powell, J., and Braun, D. P.: A method for assessing hydrologic alteration within ecosystems, 
Conserv. Biol., 10, 1163-1174, 1996.

Rientjes, T. H. M., Haile, A. T., Kebede, E., Mannaerts, C. M. M., Habib, E., and Steenhuis, T. S.: Changes in land cover, rainfall and stream flow in Upper Gilgel Abbay catchment, Blue Nile basin - Ethiopia, Hydrol. Earth Syst. Sci., 15, 1979-1989, doi:10.5194/hess-15-1979-2011, 2011.

Rodionov, S. N.: A sequential algorithm for testing climate regime shifts, Geophys. Res. Lett., 31, 9204, doi:10.1029/2004GL019448, 2004.

Rodionov, S. N.: A brief overview of the regime shift detection methods Large-Scale Disturbances (Regime Shifts) and Recovery in Aquatic Ecosystems: Challenges for Management Toward Sustainability, edited by: Velikova, V. and Chipev, N., 2005.

Rodionov, S. N. and Overland, J. E.: Application of a sequential regime shift detection method to the Bering Sea ecosystem, ICES Journal of Marine Science: Journal du Conseil, 62, 1054-3139, 2005.

Steele-Dunne, S., Lynch, P., McGrath, R., Semmler, T., Wang, S., Hanafin, J., and Nolan, P.: The impacts of climate change on hydrology in Ireland, J. Hydrol., 356, 28-45, 2008.

Taylor, W. A.: Change-point analysis: A powerful new tool for detecting changes, preprint, available at: http://www.variation.com/ cpa/tech/changepoint.html, last access: 10 March 2011, 2000a.

Taylor, W. A.: Change-Point Analyzer 2.3 software package, Taylor Enterprises, Libertyville, Illinois, available at: http:// www.variation.com/cpa/index.html, last access: 10 March 2011, 2000b.

Thodsen, H.: The influence of climate change on stream flow in Danish rivers, J. Hydrol., 333, 226-238, 2007.

Timilsena, J., Piechota, T., Tootle, G., and Singh, A.: Associations of interdecadal/interannual climate variability and long-term colorado river basin streamflow, J. Hydrol., 365, 289-301, 2009.

Tu, M.: Assessment of the effects of climate variability and land use change on the hydrology of the Meuse river basin, $\mathrm{PhD}$ thesis. UNESCO-IHE Institute for Water Education, Delft/Vrije Universiteit, Amsterdam, The Netherlands, 177, 2006.

Uhlenbrook, S.: Climate and man-made changes and their impacts on catchments, in: Water Policy 2009, Water as Vulnerable and Exhaustible Resources, edited by: Kovar, P., Maca, P., and Redinova, J., Proceedings of the Joint Conference of APLU and ICA, Prague, Czech Republic, 81-87, June, 2009.
Wang, S. H. and Xu, X.: Analysis of non-staple economy in China, Ecol. Econ., 7, 17-20, 2002, (in Chinese).

Wolfe, B. B., Hall, R. I., Edwards, T. W. D., Jarvis, S. R., Sinnatamby, R. N., Yi, Y., and Johnston, J. W.: Climate-driven shifts in quantity and seasonality of river discharge over the past 1000 years from the hydrographic apex of North America, Geophys. Res. Lett., 35, L24402, doi:10.1029/2008GL036125, 2008.

$\mathrm{Xu}, \mathrm{J}$. : Variation in annual runoff of the Wudinghe River as influenced by climate change and human activity, Quatern. Int., 244, 230-237, doi:10.1016/j.quaint.2010.09.014, 2011.

Xu, Y. H., Zheng, Y. F., Liu, X. L., and Su, F. R.: Climate Change Analysis in Recent 50 Years in Ordos, Meteorology Journal of Inner Mongolia, 2009 (in Chinese with English abstract).

Yan, Y., Yang, Z., Liu, Q., and Sun, T.: Assessing effects of dam operation on flow regimes in the lower Yellow River, Procedia Environmental Sciences, 2, 507-516, 2010.

Yang, T., Zhang, Q., Chen, Y. D., Tao, X., Xu, C., and Chen, X.: A spatial assessment of hydrologic alteration caused by dam construction in the middle and lower Yellow River, China, Hydrol. Process., 22, 3829-3843, 2008.

Yang, X., Yan, J., and Liu, B.: The analysis on the change characteristics and driving forces of Wuding River runoff, Adv. Earth Sci., 20, 637-642, 2005.

Zhang, Y. K. and Schilling, K.: Increasing streamflow and baseflow in Mississippi River since the 1940s: Effect of land use change, J. Hydrol., 324, 412-422, 2006

Zhang, Z. Z., Mu, X. M., Wang, F., Liu, Y. L., and Wang, J.: Relationship Between Cultivated Land Change and Food Security in Yulin City, Research of Soil and Water Conservation, 16, 160164, 2009 (in Chinese with English abstract).

Zhao, F. F., Xu, Z. X., Zhang, L., and Zuo, D. P.: Streamflow response to climate variability and human activities in the upper catchment of the Yellow River Basin, Science in China Series E: Technological Sciences, 52, 3249-3256, 2009.

Zhou, Y.: Sampling frequency for monitoring the actual state of groundwater systems, J. Hydrol., 180, 301-318, 1996. 